\title{
Influence of Students' Understanding and Goal Commitment on Academic Achievement in Introductory Technology in Akwa Ibom State, Nigeria
}

\author{
Godwin A. Akpan (Corresponding Author) \\ Department of Vocational Education, University of Uyo \\ Uyo, Akwa Ibom State, Nigeria \\ Tel: 234-802-392-8267Ｅ-mail: akpanga2020@yahoo.com \\ Uduak G. Mbaba \& Aniefiok E. Udofia \\ Department of Vocational Education, University of Uyo \\ Uyo, Akwa Ibom State, Nigeria
}

Received: September 28, 2011

Accepted: October 27, 2011 Published: April 1, 2012

doi:10.5539/ies.v5n2p44

URL: http://dx.doi.org/10.5539/ies.v5n2p44

\begin{abstract}
The study examined the influence of students' understanding and goal commitment on their academic achievement in Introductory Technology in secondary schools in Akwa Ibom State, Nigeria. An ex-post facto survey design was used and a random sample of 2,500 junior secondary three (13-14 years old) students from a population of 48,302 JSS three students in the state public schools in 2008/2009 session. Data on independent variables were gathered with researchers - developed instrument called Students’ Understanding and Goal Commitment in Introductory Technology (SUGCIT). The instrument had a Kuder-Richardson (KR-21) computed reliability index of .86. The data on students' academic achievement were obtained from Introductory Technology examination results of first semester 2008/2009. Two null hypotheses were tested at $\mathrm{P}<.05$ using the Z-test statistics and multiple analysis of variance. Results showed that: 62.4 per-cent of respondents did not understand the concept of Introductory Technology, while 37.6 per-cent did; Students who understood the concept of Introductory Technology had higher academic achievement in the subject than those who did not; 70 per-cent of the respondents were not committed to the pursuit of engineering/technology after the high school, while 30 per-cent were committed; Students who were committed to technology had higher achievement in Introductory Technology than those who were not. It was recommended that more proactive policies should be put in place by government and other agencies to provide technology - friendly environment and qualified staff in schools for effective teaching of Introductory Technology in order to stimulate youth interest in technology.
\end{abstract}

Keywords: Goal commitment, Self concept, Academic achievement, Introductory technology

\section{Introduction}

Introductory Technology is one of the pre-vocational subjects offered in secondary schools in Nigeria in line with the provisions of the National Policy on Education. According to the Federal Republic of Nigeria in the 2004 revised version of the educational policy, pre-vocational training is offered to students at the junior secondary school level for the purposes of:

a) Introduction to the world of technology and appreciation of technology towards interest arousal and choice of a vocation at the end of junior secondary school and professionalism later in life;

b) Acquiring technical skills;

c) Exposing students to career awareness by exploring usable options in the world of work; and

d) Enabling youths to have an intelligent understanding of the complexity of technology (p.30).

Introductory Technology curriculum is fashioned in line with the Industrial Arts curriculum offered in high schools in the United States of America, which deals with exploratory activities in the areas of metalwork, woodwork, technical drawing, electrical installation and electronics as they relate to industries. Just like the Industrial Arts 
Curriculum, the purpose of Introductory Technology is to enable students have orientation and exploration to the world of work through an appreciation of technology in the proper use of tools, equipment and materials. The subject is offered in order to stimulate students' interest that would lead to further education and training in technology disciplines and effective utilization of technology in the solution of daily problems.

Despite governments effort to encourage the study of Introductory Technology, students do not seem to be interested in the subject. The situation in most secondary schools in Nigeria reveals the poor state of facilities and lack of well equipped laboratory for the teaching of Introductory Technology (Olaniyan \& Ojo, 2008). The name Introductory Technology has recently been changed to Basic Technology but the curriculum of Introductory Technology is still maintained.

Some schools have dilapidated facilities and operate without essential tools, equipment and materials. Teachers still manage to teach even with the poor facilities, while some do selective teaching. Studies by Paiko (2008) and Uka (2008) have indicated: (i) that technical teachers are in short supply in schools; (ii) lack of relevant facilities and equipment for the teaching of technical subjects; (iii) that the few technical teachers may not have received adequate training and therefore require in-service training. All these have adversely affected the teachers' competence and students' academic achievement. The question is, in the face of all these inhibitions, how do students understanding of the concept of Introductory Technology and commitment to future academic pursuits influence their achievement in Introductory Technology?

As the world is gradually turning to a global village, due to developments in science and technology, the International Technology Education Association (ITEA, 1993) and Technology for all Americans Project (TAAP, 1996) had indicated that one of the goals of Technology Education is to promote technological literacy of a broad and encompassing nature. This involves the preparation of students to understand, control and use technology efficiently. Besterfield-Sacre, Atman and Shuman (1995) reported variables which relate to students attitude towards Technology to include gender and educational experiences. Their report implies that students academic standing in any technology subject relates to students' attitudes toward engineering and themselves.

In the United States of America, a study by Bame and Dugger (1989) carried out on high school students' attitude toward technology indicated that students' gender and age, parents' professions, and technological climate at home have relative influences on students' self-concept and their commitment to the pursuit of engineering and technology. Hemmings (1996) in Australia showed a positive relationship between students' achievement at year 12 and their expression of firm commitment to education/vocational goals at year 10. The implication here is that students that have the desire to pursue further studies in Engineering, Technology or Technical Vocational Education in their junior years in the high school are more likely to have higher academic achievement and remain to complete the school programme than those who do not have such desire. Such studies have been very scanty in Nigeria and departments in tertiary institutions offering Engineering, Technology and Technical Education continue to suffer declined enrolment as students prefer other disciplines. This situation prompted this study to determine how students commitment to the pursuit of Engineering/Technology and their understanding of the concept of Introductory Technology can influence their academic achievement in the subject.

\section{Purpose of the Study}

The study investigated the influence of students' understanding of the concept and their commitment to the pursuit of Engineering/Technology on students' academic achievement in Introductory Technology. Specifically, the objectives were to determine whether there are differences in students' academic achievement in Introductory Technology (IT) based on:

1) Students' understanding of the concept of Introductory Technology (SUCIT);

2) Students' commitment to the pursuit of further studies in Engineering/Technology disciplines (SCPET).

The following null hypotheses were tested at .05 level of significance:

$\mathrm{Ho}_{1}$ : There is so significant difference in academic achievement between students' who understand the concept of Introductory Technology and those who do not understand.

$\mathrm{Ho}_{2}$ : There is no significant difference in academic achievement between students who are committed to the pursuit of engineering/technology and those who are not committed.

\section{Research Method}

This study was carried out in Akwa Ibom State. The state is currently the largest producer of crude oil in Nigeria with multinational oil companies and allied companies in the downstream requiring skilled Nigerian personnel in engineering and technology disciplines. Introductory Technology provides the appreciation which stimulates 
students' interest Engineering and Technology.

An ex-post facto survey design was used for this study. Forty eight thousand, three hundred and two Junior Secondary Three (JSS III) students from the 227 public secondary schools in Akwa Ibom State, Nigeria constituted the population of the study (State secondary Education Board 2008/2009). Two thousand five hundred JSS III (13-14 years old) students were randomly selected from 50 schools and surveyed out of the population of 48,302 students.

Data were collected with two researchers-developed instruments namely:

a) Students Understanding and Goal Commitment in Introductory Technology (SUGCIT).

b) Students Academic Achievement (Results) in Introductory Technology (First Terminal Examination in 2008/2009 school year)

The instrument, SUGCIT, had two sections - Sections A and B. Section A sought for demographic information of students while Section B had materials bothering on: (i) Students understanding of the concept of Introductory Technology and (ii) Students commitment to the pursuit of engineering/technology. The students understanding of the concept section sought to determine the extent to which students perceive Introductory Technology as a subject which requires (i) the application of scientific principles, (ii) application of mathematical principles, (iii) students exposure to the use of tools and machines, (iv) students' to develop interest for technology/engineering, and (v) the promotion of interest in communication. The students' commitment to the pursuit of engineering/technology section sought to determine students preference or otherwise of engineering/technology disciplines after the high school. The instrument, SUGCIT, was validated and used with a KR-21 reliability index of .86. However, since the secondary school first terminal examination had already been done and each of the 50 schools administered their examinations individually, the reliability index was not determined for the second instrument.

The Mean statistics was used in answering the research questions. The hypotheses were tested using the Z-test and the multiple analysis of variance (MANOVA) at .05 alpha level.

\section{Results}

The variables of the study were coded as follows:

a) Students' understanding of the concept of Introductory Technology (SUCIT) had a maximum of 52 points. Respondents were classified as follows:

SUCIT 1 - Students who scored between 1 and 26;

SUCIT 2 - Students who scored between 27 and 52.

b) Students' commitment to the pursuit of Engineering/Technology (SCPET) also had a maximum of 52 points. The following classification were made:

SCPET 1 - Students who were not committed between 1 and 26 points;

SCPET 2 - Students who were committed to studying engineering and technology after the high school between 27 and 52 .

$\mathrm{Ho}_{1}$ : There is no significant difference in academic achievement between students who understand the concept of Introductory Technology and those who do not.

Table 1 shows that 1560 students did not understand the concept of Introductory Technology with a Mean score of 30.14, while those who understood the concept were 940 with a Mean score of 55.27. It further shows a calculated Z-value of -41.57 as against the critical value of 1.96, leading to the rejection of the null hypothesis.

$\mathrm{Ho}_{2}$ : There is no significant difference in academic achievement in Introductory Technology between students who were committed to the pursuit of further studies in engineering/technology and those who were not.

Table 2 shows that 1748 students with a Mean of 31.15 were not committed to the pursuit of engineering/technology profession, while 752 students with a Mean score of 59.20 were committed. It also shows a calculated Z of - 45.86 as opposed to the critical $\mathrm{Z}$ of 1.96 , leading to the rejection of the null hypotheses.

Analysis further showed that there is no significant difference in students academic achievement in Introductory Technology due to the joint influence of SUCIT and SCPET. The conclusion was based on the multiple analysis of variance (MANOVA) which showed a calculated F value of 1.13 at .286 alpha level for the joint influence of SUCIT and SCPET and $\mathrm{R}^{2}$ value of .491 . It therefore means that SUCIT and SCPET jointly account for 49 per cent of students' academic achievement in Introductory Technology. 


\section{Discussion of Findings}

Results showed that 62.4 per cent of the 2500 respondents with a Mean of 30.14 did not understand the concept of Introductory Technology, while 37.6 per cent with a Mean of 55.27 did understand. This clearly shows that students' who understood the concept performed better than those who did not. The Z-test of Mean comparison showed a significant value of -41.57 when compared with the critical $\mathrm{Z}$ value of 1.96 at .05 alpha level. The implication here is that students' achievement in Introductory Technology correlates with their understanding of its concept. This agrees with Hemmings (1996).

Analysis on SCPET showed that 69.9 per cent of the students with a Mean of 31.15 were not committed to pursuing engineering/technology on completion of high school, while 30.1 per-cent with a Mean of 59.20 were committed. Apparently the Mean values indicate that students who plan to pursue further studies in engineering or technology tend to perform better than those who do not. A comparison of Mean scores using the Z-test yielded a significant value of -45.86 when compared with the critical $\mathrm{Z}$ of 1.96 at $\mathrm{P}<.05$. This showed that there is a significant relationship between commitment to the pursuit of further studies in engineering/technology and students performance in Introductory Technology. This is in line with Bame and Dugger (1989).

What this study has obviously revealed is the fact that despite the important role of technology for the solution of human problems, students in secondary schools in Akwa Ibom State of Nigeria do not understand the concept and purpose of Introductory Technology. This situation has resulted in poor students' attitude and poor performance in the subject. The fact that the $21^{\text {st }}$ century world is now being activated by technology which has permeated all aspects of human endeavours cannot be overemphasized. Furthermore, the global economic meltdown which has impoverished many individuals and governments leading to the closure of businesses and serious unemployment has made people and government to realize the need for developing entrepreneurial skills through adequate Technology Education. This would enhance sustained economic development and self reliance.

Actually, government is not doing enough to stimulate students' interest in Introductory Technology as a preliminary level of technological studies. The teaching of Introductory Technology, like other technical subjects, has been hampered by problems including lack of qualified teachers, lack of hand tools, equipment and instructional materials. Introductory Technology is only the provision of a technology - friendly learning environment and teachers' utilization of appropriate teaching strategies that can stimulate students' interest and improve their academic achievement in Introductory Technology (Mbaba, 2009).

\section{Educational Implications of the Findings}

An educational implication of the findings of this study is that since students academic achievement in Introductory Technology correlates with their understanding of the concept of technology and their commitment to the pursuit of engineering/technology courses after their secondary school education, they need to be motivated to develop interest in technology through the use of appropriate technology orientation programmes during their secondary school education. Another implication is that if technology-friendly home and school environments are provided, students would be encouraged to develop interest in technology. Development of interest and positive attitude in technology would in turn lead to improved academic achievement in Introductory Technology. Furthermore, the finding that students' understanding of the concept of Introductory Technology (SUCIT) and students' commitment to the pursuit of engineering/technology (SCPET) jointly account for 49 per cent of students' academic achievement in Introductory Technology suggests that there are other factors responsible for students academic achievement in Introductory Technology which need to be investigated and addressed.

\section{Conclusion}

The teaching of Introductory Technology must be encouraged in Nigeria as a basis or pre-requisite for technology education and industrialization. Effective teaching would lead to students' understanding of the role and concept of technology and stimulate students' commitment to the pursuit of engineering and technology. When people are educated and skilled in technology they would secure gainful employment or generate jobs for themselves and others.

\section{Recommendations}

Akwa Ibom State government should encourage the teaching of Introductory Technology through proactive policies by providing a technology-friendly learning environment in schools such as hand tools, machines, well lit and ventilated laboratory, instructional materials, qualified teachers and computers for the solution of problems in Introductory Technology. Teachers should use appropriate teaching strategies for the teaching of the subject, especially the ones that will ensure active participation of students and problem solving. The current teachers on ground should be exposed to retraining in order to equip them to teach Introductory Technology as an integrated 
subject; they should be properly supervised.

\section{References}

Bame, E. A., \& Dugger, W. E. Jnr. (1989). Pupils attitude toward technology - PATT-USA Report Findings. PATT-USA in Teacher Education for School Technology (Eds. Klerk, W. et al).

Besterfield-sacre, M. Atman, C., \& Shuman, L. J. (1995). How freshman attitudes change in the first year. Report Patt 4 Conference Eindhoven, Pedagogical Technology College. Annual Conference Proceedings. Washington: ASEE.

Federal Republic of Nigeria. (2004). National policy on education. Lagos: Lagos: NERDC Press

Hemmings, B. C. (1996). A longitudinal study of Australian senior secondary school achievement. Issues in Educational Research, 6(1), 13-37.

International Technology Education Association. (1993). ITEA strategic plan: Advancing technological literacy. Reston, VA: ITEA.

Mbaba, U. G. (2009). Encouraging gender equality in secondary education: Implications of teaching strategies and students' gender on academic performance in introductory technology. Nigerian Journal of Curriculum Studies, 4, 61-74.

Olaniyan, D. A., \& Ojo, L. B. (2008). Challenges against implementation of introductory technology curriculum in Nigerian junior secondary schools. European Journal of Scientific Research, 24(1). 112-118.

Paiko, E. J. (2008). Technical education as qualify assurance of youth capacity building mechanism. A paper presented at the $21^{\text {st }}$ National Conference of Teachers of Technology held from $20^{\text {th }}-24^{\text {th }}$ October.

Uka, J. A. U. (2008). Factors affecting students' poor academic performance in technical colleges in Rivers State. A paper presented at the $21^{\text {st }}$ National Conference of the Nigerian Association of Teachers of Technology held from 2oth $-24^{\text {th }}$ October.

Table 1. Z-test of mean comparison between SUCIT 1 and SUCIT 2

\begin{tabular}{|l|l|l|l|l|l|}
\hline Variable & $\mathrm{N}$ & Mean & SD & Df & Zcal \\
\hline SUCIT 1 & 1560 & 30.14 & 13.48 & 2498 & $-41.57^{*}$ \\
\hline SUCIT 2 & 940 & 55.27 & 16.36 & & \\
\hline
\end{tabular}

SUCIT 1 = students who did not understand the concept of IT.

SUCIT 2 = Students who understood the concept of IT

Table 2. Z-test of mean comparison between SCPET 1 and SCPET 2

\begin{tabular}{l}
\begin{tabular}{|l|l|l|l|l|l|}
\hline Variable & $\mathrm{N}$ & Mean & SD & Df & Zcal \\
\hline SCPET 1 & 1748 & 31.15 & 13.81 & 2498 & $-45.86^{*}$ \\
\hline SCPET 2 & 752 & 59.20 & 14.50 & & \\
$\mathrm{p}<.05$
\end{tabular} \\
\hline
\end{tabular}

SCPET 1 - Students who were not committed to the pursuit of engineering/technology

SCPET 2 - Students who were committed to pursue engineering/technology

Table 3. MANOVA of test between subjects effects with SAAIT as a dependent variable

\begin{tabular}{|l|l|l|l|l|l|}
\hline Source of Variation & Sum of squares & df & MS & F & Sig \\
\hline Intercept & 1044014.99 & 1 & 1044014.99 & 5659.18 & .000 \\
\hline SUCIT & 14120.05 & 1 & 14120.05 & 76.53 & .000 \\
\hline SCPET & 48623.63 & 1 & 48623.63 & 263.56 & .000 \\
\hline SUCIT - SCPET & 210.16 & 1 & 210.16 & 1.13 & .286 \\
\hline Error & 460465.95 & 2496 & 184.48 & & \\
\hline Total & 905241.28 & 2499 & & & \\
\hline
\end{tabular}

R Squared $=.491$

SAAIT - Students academic achievement in introductory technology 